\title{
The Analysis of Step Count in 12- and 13-year-old Children Attending All-Day or Double-Shift School: Tekirdağ Province Sample
}

\section{Normal ve İkili Ĕ̆itim Verilen Okullara Devam Eden 12-13 Yaş Grubundaki Çocukların Adım Sayılarının İncelenmesi: Tekirdă̆ İli Örneği}

\author{
Pınar Öztürk Erol ${ }^{1}$, Niyazi Eniseler², Turan Işık³, Ayda Karaca ${ }^{4}$ \\ ${ }^{1}$ Güngören Şiir Mektebi Secondary School, Ministry of Education, İstanbul, Turkey \\ ${ }^{2}$ Fenerbahçe Sports Club, İstanbul, Turkey \\ ${ }^{3}$ Department of Coaching Education, Faculty of Sport Sciences, Celal Bayar University, Manisa, Turkey \\ ${ }^{4}$ Department of Recreation, Faculty of Sport Sciences, Hacettepe University, Ankara, Turkey
}

\begin{abstract}
P. Öztürk Erol
0000-0001-6298-0321

$\mathrm{N}$. Eniseler

0000-0003-3883-4994

T. Işık

0000-0001-8047-510X

A. Karaca in
\end{abstract}

0000-0002-3189-2385

Geliş Tarihi/Date Received: 28.06.2019

Kabul Tarihi/Date Accepted: 16.08.2019

Yayin Tarihi/Published Online: 14.01.2019

Yazışma Adresi /

Corresponding Author:

Ayda Karaca

Hacettepe Üniversitesi, Spor

Bilimleri Fakültesi, Rekreasyon

Bölümü, Ankara, Turkey

E-mail: aydakaraca@gmail.com

(C2020 Türkiye Spor Hekimleri

Derneği. Tüm hakları saklıdır.

\section{ABSTRACT}

Purpose: The study aimed to analyze the average daily step counts of 12- and 13year-old children in all-day or double-shift schools for defined periods.

Materials and Methods: Sixty students ( 30 all-day, 30 double-shift) participated in the study; their mean age was $12.5 \pm 0.5$ years. Children were asked to wear FitbitFlex 2 accelerometer on their dominant wrist. Data were collected from children for a minimum of eight hours for seven days (minimum of four weekdays and a weekend day).

Findings: It was observed that the daily average step count of boys was higher than girls for after school, outside school, the weekend, and the entire week $(p<0.05)$. In terms of daily average step count before and after school, there was significant difference between 12 - and 13 -year-old children $(\mathrm{p}<0.05)$. The daily average step count for children in all-day education was higher than that of children in double-shift schooling for during school, after school, and weekdays $(p<0.05)$. The average daily step count before school in the double-shift school was higher than that in all-day school $(p<0.05)$. More than half of both girls and boys did not achieve recommended daily step counts.

Conclusion: The daily step count of boys was higher than girls. The step count of children during school in all-day education was higher than that of children in doubleshift education. It was determined that the majority of students did not succeed to reach recommended step counts during school, and more than half failed to reach daily recommended step counts.

Keywords: Physical activity, children, step count

ÖZ

Amaç: Normal ve ikili eğitim verilen okullara devam eden, aktif ulaşım kullanmayan ve yapılandırılmış spor aktivitesine katılmayan 12 ve 13 yaşlarındaki çocukların; beden eğitimi dersinde, okul sırasında, okul dışında, hafta içi, hafta sonu ve tüm hafta için günlük adım sayılarını incelemek ve önerilen düzeyde fiziksel aktif olup olmadıklarını belirlemektir.

Gereç ve Yöntemler: Çalışmaya normal eğitim verilen okuldan 30 (16 kız, 14 erkek), ikili eğitim verilen okuldan 30 (15 kız, 15 erkek) olmak üzere yaş ortalaması $12.5 \pm 0.5$ olan 60 öğrenci katıldı. Çocuklardan Fitbit Flex 2 marka akselerometreyi yedi gün boyunca dominant el bileklerine giymeleri istendi. Günde en az sekiz saat olması koşuluyla hafta içi en az dört gün, hafta sonu en az bir günlük verisi olan çocukların verileri çalışmaya dahil edildi. 


\begin{abstract}
Bulgular: Erkek çocukların okuldan sonra, okul dışı, hafta içi ve tüm haftaya ait günlük ortalama adım sayılarının kız çocuklardan daha fazla olduğu belirlendi $(p<0.05)$. Okuldan önce ve okuldan sonra günlük ortalama adım sayıları bakımından 12 ve 13 yaş çocuklar arasında istatistiksel olarak anlamlı fark bulundu $(p<0.05)$. Normal eğitim verilen okullara devam eden çocukların okul sırasında, okul sonrasında ve hafta içi günlerde günlük ortalama adım sayılarının ikili eğitim verilen okullara devam eden çocuklardan daha fazla olduğu; okuldan önce atılan günlük adım sayının ikili eğitim verilen okullara devam eden çocuklarda daha yüksek olduğu gözlendi $(p<0.05)$. Hem kız hem de erkek çocukların yarısından fazlasının günlük önerilen adım sayısına ulaşamadığı belirlendi.

Sonuç: Erkek çocukların günlük adım sayısının kız çocuklardan daha fazla olduğu, normal eğitim verilen okullara devam eden çocukların okul sırasındaki adım sayısının ikili eğitim verilen okullara devam eden çocuklardan yüksek olduğu gözlendi. Öğrencilerin büyük çoğunluğunun okul sırasında önerilen adım sayısına, yarısından fazlasının ise günlük önerilen adım sayısına ulaşamadığı saptandı.
\end{abstract}

Anahtar Sözcükler: Fiziksel aktivite, çocuklar, adım sayısı

Available at: http://journalofsportsmedicine.org and http://dx.doi.org/10.5152/tjsm.2020.164

Cite this article as: Ozturk Erol P, Eniseler N, Isik T, Karaca A. The analysis of step count in 12- and 13-year-old children attending all-day or double-shift school: Tekirdağ province sample. Turk J Sports Med. 2020;55(2):86-94.

\title{
GíRiş
}

İnaktivite ve sedanter zamanın artışı 21. yüzyılın en önemli küresel sağlık sorunları arasında yer alırken (1), sağlıklı yaşam biçiminin önemli bileşenlerinden birinin fiziksel aktivite (FA) olduğu $(2,3)$ ve yaşamın ilerleyen dönemlerinde oluşabilecek kronik hastalıklara karşı korunmada hayati bir önem taşıdığı vurgulanmaktadır (4). Yaşları 5-17 arasında olan çocuk ve ergenlerin her gün 60 dakika orta-yüksek şiddette FA yapmaları önerilmektedir (5). Tudor-Locke ve ark. (6) gün içerisinde atılması gereken adım sayısını erkek çocukları için 15000, kız çocukları için 12000 olarak vermektedir.

Dünya Sağlık Örgütü'nün (WHO) verilerine göre, 11-17 yaş arasındaki ergenlerin yeterli düzeyde FA yapmama oranı küresel olarak \%81 (kızlarda $\% 84$; erkeklerde \%78); Türkiye'de ise \%82.2 (kızlarda \%86.9; erkeklerde \%77.1) düzeyindedir (7). Erkeklerin kızlara göre her yaşta daha fazla günlük ortalama adım sayısına sahip olduğu ve adım sayılarının 12 yaşından önce en yüksek seviyeye ulaştığı, ancak ergenlik döneminde azaldığı saptanmıștır (8). Ergenlik döneminden yetişkinliğe geçişte FA'ya katılımın düşük olması, bu süreçte aktiviteye katılımın özendirilmesini önemli kılmaktadır (9).

Çocukların FA alanları serbest zaman, okul, ulaşım ve ev olmak üzere dört başlık altında ele alınmaktadır (10). Çocukların orta ve yüksek şiddetli FA'lara katılımlarının en fazla okulda ve evde olduğu belirtilmektedir $(11,12)$. Dışarıda oyun oynama, ulaşım için yürüme ve bisiklete binme eylemleri gün boyu fiziksel aktif kalmaya olanak sağlamaktadır (9). Ev ve okul arasındaki ulaşımın, çocukların FA'ları için potansiyel bir kaynak olduğu (13) ve aktif ulaşımı tercih eden çocukların günlük olarak önerilen FA düzeyine daha rahat ulaşabilecekleri belirtilmektedir (14). Aktif ulaşım kullanan çocukların motorlu ulaşım araçlarını kullananlara oranla daha yüksek FA düzeyinde oldukları belirlenmiştir (15). Okul sırasinda, okul sonrasinda ve hafta sonunda adolesanların FA düzeyini arttırma girişimlerinin yapılması önerilmektedir (16). Çocukların hafta sonlarında hafta içine göre daha aktif olma ve daha az sedanter zaman geçirme eğiliminde oldukları belirtilmektedir $(17,18)$.

FA için gerekli tesis, ekipman ve personeli bulunan okullar, çocuk ve ergenleri FA'ya yönlendirmek için ideal ortamı sunabilmektedir (19). Smith ve ark. (20) çocukların yüksek şiddette FA yapabilecekleri aktivite alanlarından birinin beden eğitimi dersi olduğunu savunmaktadır. Okullardaki FA çalışmalarının önemli bir bölümü, beden eğitimi dersinde yapılandırılmış ortamda gerçekleştirilmektedir (21). Çocukların beden eğitimi dersinin olduğu günlerde, bu dersin olmadığı günlere göre daha aktif bulunduğu belirtilmektedir (22). Çocuklar okul saatlerinin büyük bir bölümünde çok fazla aktif olmasalar da, beden eğitimi dersleri ve teneffüslerin FA düzeylerinin arttırılmasında önemli rol oynaması $(21,23)$ nedeniyle, önerilen günlük ortalama adım sayısının yarısının (6000 adım/gün) okullarda karşılanması beklenmektedir (23). 
Çocuklar yaklaşık olarak günün üçte birini okulda geçirmektedir (24). Dolayısıyla bu önemli zaman diliminde normal veya ikili eğitim veren okullara devam eden, aktif ulaşım kullanmayan ve yapılandırılmış spor aktivitesine katılmayan 12 ve 13 yaşlarındaki çocukların beden eğitimi dersinde, okul sırasında, okul dişında, hafta içi, hafta sonu ve tüm hafta için günlük adım sayılarını incelemek ve önerilen düzeyde olup olmadığını belirlemek bu çalışmanın amacını oluşturmaktadır.

\section{GEREÇ ve YÖNTEMLER}

\section{Araștırma Grubu}

Bu çalışmanın verileri, 2018 yılının Mayıs ve Haziran aylarında Tekirdağ ilinin Çorlu ve Çerkezköy ilçelerinde toplandı. Çalışmaya, Çorlu ilçesinde normal eğitim ve Çerkezköy ilçesinde ikili eğitim gerçekleştiren iki ortaokuldan altıncı ve yedinci sınıfa (12-13 yaş) devam etmekte olan 60 öğrenci alındı. 30 öğrenci (16 kız, 14 erkek) normal eğitim yapan okuldan, diğer 30 öğrenci (15 klz, 15 erkek) ise ikili eğitim yapan okuldan seçildi. Çocukların yaş ortalamaları $12.5 \pm 0.5$, boy ortalamaları $157.2 \pm 8.1 \mathrm{~cm}$, vücut ağırlığı ortalamaları $50.5 \pm 10.5 \mathrm{~kg}$ ve beden kitle endeksi ortalamaları $20.3 \pm 3.3$ idi. Çalışmaya okullarında haftada $80 \mathrm{dk}(40+40 \mathrm{dk})$ beden eğitimi dersine katılan, ancak okul dışında yapılandırılmış spor aktivitelerine katılmayan, aktif ulaşımı kullanmayan öğrenciler seçildi. Çalışma için Manisa Celal Bayar Üniversitesi Tıp Fakültesi Sağlık Bilimleri Etik Kurulundan izin alındı.

Normal eğitim; sabah ve öğleden sonrayı kapsayacak şekilde yapılan eğitim, ikili eğitim; sabah ve öğleden sonra ayrı yapılan eğitim şeklinde tanımlanmaktadır. Ders, teneffüs, öğle arası, ders başlangıç ve bitiş saatleri Milli Eğitim Bakanlığı Okul Öncesi Eğitim ve İlköğretim Kurumları Yönetmeliği çerçevesinde uygulanmaktadır (25). Bu çalışmada ikili eğitim yapan okulda sabah grubunun ders başlangıç ve bitiş saatleri 08:00-13:20; öğle grubunun ders başlangıç ve bitiş saatleri 13:30-18:50 olarak uygulanmaktadır. Normal eğitim verilen okulda ise ders başlangıç ve bitiş saatleri 08:30-15:20 olarak uygulanmaktadır. İkili eğitim verilen okullara devam eden öğrencilerin okulda bulundukları süre 5 saat 20 dakika iken, normal eğitim verilen okullara devam eden öğrencilerin okulda bulundukları süre 6 saat 50 dakikadır. Her iki okulda da günde toplam yedi ders yapılmaktadır ve her bir ders saati 40 dakikadır. Teneffüs süreleri okul yönetimi tarafından belirlenmektedir.

\section{Veri Toplama Araçları}

Kişisel bilgi formu: Araştırmacılar tarafından hazırlanan form altı sorudan oluşmaktadır.

Akselerometre: Çocukların FA düzeylerinin belirlenmesinde Fitbit marka, Flex2 model akselerometre (Fitbit Inc, San Francisco, CA, USA) kullanılmıştır. Cihazın plastik bir kordon içine takılan elektronik aksamı bulunmaktadır. $\mathrm{Bu}$ aksam 23.5 g ağırlığında ve $31.7 \times 8.9 \times 6.8 \mathrm{~mm}$ ölçülerindedir (26).

\section{Verilerin Toplanması}

Kişisel bilgi formunun uygulanması: Araştırmacılar tarafından hazırlanan kişisel bilgi formu sınıf ortamında görüşme yöntemiyle uygulanarak dolduruldu.

Fiziksel aktivite düzeylerinin belirlenmesi: Yedi gün süresince Fitbit Flex 2 akselerometre ile kaydedilen veriler Bluetooth 4.0 bağlantı yolu ile bilgisayar ortamına aktarıldı ve Fitbit web sayfasındaki kullanıcı girişlerine eklendi. Cihaz öğrencilere birinci gün ilk ders saatinde dağıtıldı ve dominant el bileklerine giymeleri istendi. Yedi gün tamamlandıktan sonraki ilk ders saatinde geri alındı. Cihazlar giyildikten dört gün sonra, çocukların inaktif olduğu bir ders saatinde şarj edilmek için toplandı ve ders sonunda giyilmek üzere çocuklara geri verildi.

Cihazın uyku, duş ve yüzme gibi durumlarda çıkarılmasına gerek olmadığl, ancak istendiği takdirde çıkarılmasında sakınca olmadığı belirtildi ve gece yatarken çıkarılması durumunda sabah uyanır uyanmaz giyilmesi istendi. Ölçümlerin geçerli olabilmesi için Fitbit Flex 2'nin yedi gün boyunca giyilmesinin önemi belirtildi. Gün içerisinde en az sekiz saat olmak koşuluyla, hafta içi en az dört gün, hafta sonu en az bir gün olmak üzere toplam en az beş günlük verisi olan çocukların verileri çalışmaya alındı. Ölçümler 
öncesinde çocuklara ve ebeveynlerine detaylı bilgilendirme yapıldı. Ölçümlerin yapıldığı günlerde ortalama hava sıcaklığı $23-27^{\circ} \mathrm{C}$ aralığında idi. Hafta içinde resmi tatillere denk gelen günlerde ölçüm alınmadı. Her gün için toplanan veriler farklı zaman dilimlerine (beden eğitimi dersi, okul sırasında, okul dışında (okul öncesi ve okul sonrası), hafta içi, hafta sonu ve tüm hafta) ayrllarak incelendi.

\section{Veri Analizi}

Analizde kullanılacak değișkenler için tanımlayıcı istatistikler ortalama \pm standart sapma (SS) olarak verildi. Verilerin analizine geçilmeden önce her bir değişken için normallik ve varyansların homojenliği test edildi. Bağımsız iki grup (kız-erkek; 12-13 yaş; normal ve ikili eğitim veren okullar) arasında farklılık olup olmadığını test etmek için iki ortalama arasındaki farkın anlamlılık testi (Student's t test) uygulandı. Öğrencilerin önerilen adım sayılarına ulaşıp ulaşamadıkları sayı ve yüzde olarak verildi. Verilerin analizinde SPSS Statistics 23.0 programı ve 0.05 yanılma düzeyi kullanıldı.

\section{BULGULAR}

Bu çalışmada 12-13 yaşlarındaki (6. ve 7. sınıf) öğrencilerin okul sırasında ve okul dışında, hafta içi ve hafta sonunda ve beden eğitimi dersinde ulaştıkları adım sayıları bakımından cinsiyet, yaş grupları ve okullarının normal ve ikili eğitim olma durumlarına göre fark olup olmadığı ve ayrıca öğrencilerin adım sayılarının önerilen düzeyde olup olmadığı incelendi (Tablo 1 ve 2).

Erkek çocukların okul dışında, okuldan sonra, hafta içinde ve tüm haftaya ait günlük ortalama adım sayıları kız çocukların adım sayılarından fazla bulundu $(\mathrm{p}<0.05)$. Beden eğitimi dersinde, okul sirasinda, okuldan önce ve hafta sonunda günlük ortalama adım sayıları bakımından cinsiyetler arasında istatistiksel olarak anlamlı fark olmadığı saptandı ( $\mathrm{p}>0.05)$ (Tablo 1).

Tablo 1. Çocukların farklı zaman dilimlerinde ulaştıkları günlük ortalama adım sayılarının cinsiyete göre incelenmesi

\begin{tabular}{lcccccc}
\hline & \multicolumn{2}{c}{ Kız (n=31) } & \multicolumn{2}{c}{ Erkek (n=29) } & \multicolumn{1}{c}{ p } \\
\cline { 2 - 5 } & Ort. & Ss & Ort. & Ss & t & p \\
\cline { 2 - 5 } Beden eğitimi dersinde (adım/ders) & 2596,65 & 1266,73 & 2915,38 & 1445,33 & $-0,91$ & 0,367 \\
Okul sırasında (adım/gün) & 4246,41 & 1484,23 & 4942,88 & 1382,54 & $-1,87$ & 0,066 \\
Okul dıșında (adım/gün) & 7294,18 & 2443,02 & 9103,09 & 2403,13 & $-2,88$ & $0,005^{*}$ \\
$\quad$ Okuldan önce (adım/gün) & 1590,88 & 767,777 & 1947,6 & 1167,52 & $-1,4$ & 0,165 \\
$\quad$ Okuldan sonra (adım/gün) & 5703,3 & 2515,75 & 7155,5 & 2717,17 & $-2,15$ & $0,036^{*}$ \\
Hafta içinde (adım/gün) & 11540,6 & 3125,83 & 14045,9 & 3048,56 & $-3,14$ & $0,003^{*}$ \\
Hafta sonunda (adım/gün) & 11961,4 & 4790,75 & 12510,8 & 5381,19 & $-0,41$ & 0,677 \\
Tüm hafta (adım/gün) & 11660,8 & 3149,18 & 13607,3 & 2913,36 & $-2,48$ & $0,016^{*}$ \\
\hline *: $p<0.05$ & & & & & &
\end{tabular}

Yaşlarına göre kıyaslandıklarında; 12 yaşındaki çocukların okuldan önce ortalama adım sayılarının 13 yaşındaki çocuklardan yüksek olduğu, 13 yaşındaki çocukların ise okuldan sonra ortalama adım sayılarının 12 yaşındaki çocuklardan yüksek olduğu belirlendi $(\mathrm{p}<0.05)$. Beden eğitimi dersinde, okul sirasında, okul dışında, hafta içinde, hafta sonunda ve tüm haftaya ait ortalama adım sayıları bakımından 12 ve 13 yaşındaki çocuklar arasında istatistiksel olarak anlamlı fark olmadığı saptandı $(p>0.05)$ (Tablo 2).
Normal eğitim yapan okula devam eden çocukların okul sırasında, okul sonrasında, hafta içinde ortalama adım sayıları ikili eğitim yapan okula devam eden çocukların ortalama adım sayılarından yüksek bulundu $(\mathrm{p}<0.05)$. Okuldan önceki günlük ortalama adım sayısı ise ikili eğitim yapan okullarda daha yüksekti $(\mathrm{p}<0.05)$. Okul dışında, hafta sonunda ve tüm hafta boyunca günlük ortalama adım sayıları bakımından tam gün ve ikili eğitim yapan okullar arasında istatistiksel olarak anlamlı fark saptanmadı ( $\mathrm{p}>0.05$ ) (Tablo 3). 
Tablo 2. Çocukların farklı zaman dilimlerinde ulaştıkları günlük ortalama adım sayılarının yaşa göre incelenmesi

\begin{tabular}{|c|c|c|c|c|c|c|}
\hline & \multicolumn{2}{|c|}{12 yaş $(n=30)$} & \multicolumn{2}{|c|}{13 yaş $(n=30)$} & \multirow{2}{*}{$\mathbf{t}$} & \multirow{2}{*}{$\mathbf{p}$} \\
\hline & Ort. & Ss & Ort. & Ss & & \\
\hline Beden eğitimi dersinde (adım/ders) & 2504,07 & 1145,8 & 2997,33 & 1513,49 & $-1,423$ & 0,16 \\
\hline Okul sırasında (adım/gün) & 4559,35 & 1489,4 & 4606,72 & 1468,18 & $-0,124$ & 0,902 \\
\hline Okul dışında (adım/gün) & 7548,91 & 2345,47 & 8788,07 & 2673,04 & $-1,909$ & 0,061 \\
\hline Okuldan önce (adım/gün) & 2263,81 & 1156,01 & 1262,79 & 370,125 & 4,517 & $0,000 *$ \\
\hline Okuldan sonra (adım/gün) & 5285,11 & 2449,18 & 7525,29 & 2484,16 & $-3,517$ & $0,001^{*}$ \\
\hline Hafta içinde (adım/gün) & 12108,2 & 3364,71 & 13394,7 & 3185,39 & $-1,521$ & 0,134 \\
\hline Hafta sonunda (adım/gün) & 12439,4 & 5231,6 & 12014,4 & 4939,05 & 0,324 & 0,747 \\
\hline Tüm hafta (adım/gün) & 12202,9 & 3093,81 & 13000,4 & 3242,11 & $-0,975$ & 0,334 \\
\hline
\end{tabular}

${ }^{*} p<0,05$

Tablo 3. Çocukların farklı zaman dilimlerinde ulaştıkları günlük ortalama adım sayılarının normal ve ikili eğitim durumuna göre incelenmesi

\begin{tabular}{lcccccc}
\hline & \multicolumn{2}{c}{ Tam Gün Eğitim (n=30) } & \multicolumn{2}{c}{ İkili Eğitim (n=30) } & \multirow{2}{*}{ t } & \multirow{2}{*}{ p } \\
\cline { 2 - 5 } & Ort. & Ss & Ort. & Ss & & \\
\hline Okul sırasında (adım/gün) & 5111,53 & 1598,77 & 4054,54 & 1114,03 & 2,971 & $0,004^{*}$ \\
Okul dıșında (adım/gün) & 8685,07 & 2704,14 & 7651,91 & 2361,39 & 1,576 & 0,12 \\
$\quad$ Okuldan önce (adım/gün) & 1465,93 & 419,539 & 2060,66 & 1277,77 & $-2,422$ & $0,019^{*}$ \\
Okuldan sonra (adım/gün) & 7219,14 & 2467,26 & 5591,25 & 2703,18 & 2,436 & $0,018^{*}$ \\
Hafta içinde (adım/gün) & 13796,6 & 3278,37 & 11706,4 & 3052,32 & 2,556 &, $013^{*}$ \\
Hafta sonunda (adım/gün) & 11170,7 & 4308,1 & 13283,1 & 5566,83 & $-1,644$ & 0,106 \\
Tüm hafta (adım/gün) & 13046,3 & 3110,42 & 12156,9 & 3213,73 & 1,089 & 0,281 \\
\hline
\end{tabular}

*: $p<0.05$

Hem kız hem de erkek öğrencilerin yarısından çoğunun hafta içi, hafta sonu ve tüm haftaya ait günlük ortalama adım sayılarının önerilen gün- lük ortalama adım sayısını karşılayamadığı saptandı (Tablo 4).

Tablo 4. Öğrencilerin hafta boyunca günlük ortalama adım sayılarının belirlenen kesim noktasına göre frekans dağılımları

\begin{tabular}{lcccc}
\hline & \multicolumn{2}{c}{ Kızlar } & \multicolumn{2}{c}{ Erkekler } \\
\cline { 2 - 5 } & $\mathbf{< 1 2 0 0 0}$ adım/gün & $\mathbf{2 1 2 0 0 0}$ adım/gün & $\mathbf{< 1 5 0 0 0}$ adım/gün & $\mathbf{2 1 5 0 0 0}$ adım/gün \\
\cline { 2 - 5 } & Sayı (\%) & Sayı (\%) & Sayı (\%) & Sayı (\%) \\
\hline Hafta içi & $18(58.1)$ & $13(41.9)$ & $17(58.6)$ & $12(41.4)$ \\
Hafta sonu & $17(54.8)$ & $14(45.2)$ & $19(65.5)$ & $10(34.5)$ \\
Tüm hafta & $16(51.6)$ & $15(48.4)$ & $16(55.2)$ & $13(44.8)$ \\
\hline
\end{tabular}

Hafta içi günlerde okul sırasındaki günlük ortalama adım sayıları incelendiğinde kızların \%90.3'ünün, erkeklerin \%82.8'inin önerilen 6000 adım sayısına ulaşamadıkları belirlendi. Hafta içi günlerde okul dışındaki günlük ortala- ma adım sayıları incelendiğinde ise kızların $\% 29.0$ 'unun, erkeklerin ise \%10.3'ünün önerilen 6000 adım sayısının altında kaldığı saptandı (Tablo 5). 
Tablo 5. Öğrencilerin hafta içi günlerde okul sırasında ve okul dışında günlük ortalama adım sayılarının belirlenen kesim noktasına göre frekans dağılımları

\begin{tabular}{|c|c|c|c|c|c|c|}
\hline & \multicolumn{2}{|c|}{ Kizlar } & \multicolumn{2}{|c|}{ Erkekler } & \multicolumn{2}{|c|}{ Toplam } \\
\hline & $\begin{array}{c}<6.000 \\
\text { adım/gün }\end{array}$ & $\begin{array}{c}\geq 6.000 \\
\text { adım/gün }\end{array}$ & $\begin{array}{c}<6.000 \\
\text { adım/gün }\end{array}$ & $\begin{array}{c}\geq 6.000 \\
\text { adım/gün }\end{array}$ & $\begin{array}{c}<6.000 \\
\text { adım/gün }\end{array}$ & $\begin{array}{c}\geq 6.000 \\
\text { adım/gün }\end{array}$ \\
\hline & Sayı (\%) & Sayı (\%) & Sayı (\%) & Sayı (\%) & Sayı (\%) & Sayı (\%) \\
\hline Okul sırasında & $28(90.3)$ & $03(09.7)$ & $24(82.8)$ & $05(17.2)$ & $52(86.6)$ & $08(13.3)$ \\
\hline Okul dışında & $09(29.0)$ & $22(71.0)$ & $03(10.3)$ & $26(89.7)$ & $12(20.0)$ & $48(80.0)$ \\
\hline
\end{tabular}

\section{TARTIŞMA}

Normal veya ikili eğitim veren okullara devam eden 12-13 yaşlarındaki kız ve erkek çocuklardan elde edilen; beden eğitimi dersinde, okul sırasında, okul dışında (okul öncesi ve okul sonrası), hafta içi, hafta sonu ve tüm hafta boyunca ulaştıkları günlük ortalama adım sayıları; cinsiyete, yaşa, okul eğitim düzenine ve önerilen adım sayısı değerlerine göre incelenmiştir.

Çocukların okul günlerinde en çok aktif olabileceği saatlerden biri beden eğitimi ders saatleridir. Brusseau ve ark. (22) beden eğitimi derslerinde erkeklerin kızlardan daha aktif olduğunu belirtmişlerdir. Bu çalışmada ise beden eğitimi dersinde adım sayıları bakımından cinsiyetler arasında istatistiksel olarak anlamlı fark elde edilmedi (Tablo 1). Bunun nedeni beden eğitimi dersinde uygulanan müfredatın her iki cinsiyet için aynı aktiviteleri içermesi olabilir.

Demirci (28) ve Klinker ve ark. (3)'nın çalışmalarında okul sırasında erkeklerin kızlardan daha aktif olduğu belirtilmiştir. Bu çalışmada okul sırasındaki adım sayısı bakımından cinsiyetler arasında fark olmadığ (Tablo 1); her iki cinsin okul sırasındaki günlük adım sayısı ortalamalarının önerilen adım sayısı olan (23) 6000 adımdan daha düşük olduğu (Tablo 5) saptandı. Bir günün yaklaşık üçte birini kapsayan okul saatlerinde (24) çok fazla aktif olmasalar da çocukların günlük adım sayısını belirleyen en önemli zaman dilimlerinden birinin teneffüsler olduğu vurgulanmaktadır $(21,23)$. Bu çalışmaya katılan kız ve erkek çocukların teneffüslerde benzer şiddette aktivitelerde bulundukları akla gelmektedir.

Tudor-Locke ve ark. (27) okul sonrasinda kız öğrencilerin ortalama adım sayısının erkek öğ- rencilerden düşük olduğunu (sırasıyla 5933 ve 7805 adım/okul sonrası); erkeklerin günlük FA'larının \%58'ini, kızların ise \%56'sını okul dışında yaptıklarını belirtmişlerdir. Beighle ve ark. (29) ise okul dışı saatlerde kız öğrencilerin erkek öğrencilerden daha az aktif olduğunu belirtmiştir. Benzer olarak bu çalışmada da kız öğrencilerin okul dişı ortalama adım sayılarının erkek öğrencilerden düşük olduğu (sırasıyla 7294 ve 9103 adım/okul dışı) saptandı $(\mathrm{p}<0.05)$ (Tablo 1). Kent ve kırsal yerleşmelerde erkek çocukların kız çocuklara oranla daha özgür olduğu ve bağımsız hareket etme konusunda kız çocuklarına getirilen kısıtlamaların daha fazla olduğu belirtilmiştir (30). Bu çalışmada da erkek çocukların okul dışı zamanlarda dışarıda daha fazla zaman geçirme olasılığ Diğer bir neden ise ebeveynlerin çocuklarının şiddet mağduru olabileceklerinden korkmaları ve özellikle de kız çocuklarının cinsel istismara uğrayabilecekleri endişesiyle (31) sokakta oynamalarına izin vermemeleri olabilir.

$\mathrm{Bu}$ çalışmada erkek çocukların hafta içi adım sayılarının kız çocuklardan daha yüksek olduğu (sırasıyla 14045 ve 11540 adım/gün) gözlendi $(\mathrm{p}<0.05)$ (Tablo 1). Benzer olarak Brusseau ve ark. (22) ve Demirci (28) çalışmalarında hafta içi günlerde erkek öğrencilerin adım sayılarının kız öğrencilerden yüksek olduğunu belirtmişlerdir. Hafta içi günlerde adım sayısını belirleyen unsurlar okul sırasında ve okul dışındaki adım sayılarıdır. Bu çalışmada okul dışı adım sayısının hafta içi adım sayısına yansıdığı görülmektedir.

Brusseau ve ark. (22)'nın çalışmasındakine benzer olarak bu çalışmada da hafta sonu adım sayıları bakımından cinsiyetler arasında istatis- 
tiksel olarak anlamlı fark olmadığı $(p>0.05)$ ve her iki cinsin hafta sonu önerilen adım sayısı ortalamalarına ulaşamadığı saptandı (Tablo 1). Dolayısıyla hem kız hem de erkek çocukların hafta sonunda sedanter aktivitelere yöneldikleri anlaşılmaktadır. Tercih edilen sedanter aktiviteler cinsiyete göre farklılaşabilmektedir. Biddle ve ark. (32) kı çocuklarının oturarak sohbet etmeyi; erkek çocuklarının ise bilgisayar oyunu oynamayı yeğlediklerini belirtmiştir. Ayrıca erkek çocukların hafta içi ortalama adım sayılarının hafta sonu değerlerden yaklaşık 1500 adım daha fazla olduğu (sırasıyla 14045 ve 12510 adım/gün) belirlendi (Tablo 1). Hafta sonu adım sayısının hafta içinden düşük olması, çocukların hafta sonu zamanlarını nasıl geçirecekleri konusunda çok fazla seçeneğe sahip olsalar da genel olarak FA yapmayı tercih etmedikleri kanısını ortaya çıkarmaktadır (18).

Çocukların gün içerisindeki ortalama adım sayıları ile önerilen adım sayısı değerleri karşılaştırılırken Tudor-Locke ve ark.'nın (6) belirlediği 12000/15000 (kı/erkek) günlük adım sayısı kesim noktası dikkate alındığında, Gauthier ve ark.'nın (24) çalışmasına benzer şekilde kızların \%48.4'ünün, erkeklerin ise \%44.8'inin önerilen adım sayısına ulaşamadıkları anlaşılmaktadır (Tablo 4).

$\mathrm{Bu}$ çalışmada erkek çocukların tüm haftaya ait günlük ortalama adım sayısı kız çocuklarından yüksektir (Tablo 1). Benzer olarak Klinker ve ark. (3) ile Tudor-Locke ve ark. (27) erkek öğrencilerin kızlardan daha aktif olduğu sonucuna ulaşmışlardır. Bu durum teneffüs (29), öğle arası (29) ve okul dışında yapılan aktiviteler $(27,29)$, ekran karşısında geçirilen süre (33), ilçede yaşıyor olmak (34) gibi nedenlerle açıklanabilir.

Gauthier ve ark. (24), Klinker ve ark. (3), Troiano ve ark. (35) ve Tudor-Locke ve ark. (36) çocuk ve adolesanlar üzerindeki çalışmalarında yaş ilerledikçe FA düzeyinin ve adım sayısının azaldığını saptamışlardır. Burns ve ark. (23) 5. sinıfta okuyan çocukların okul günlerinde ve öğle aralarında 4. sınıflardan daha aktif olduğunu belirtmişlerdir. $\mathrm{Bu}$ çalışmada 12 ve 13 yaşındaki çocukların beden eğitimi dersi, okul sırasında, okul dışında, hafta içi, hafta sonu ve tüm haftaya ait günlük ortalama adım sayısı değerleri için istatistiksel olarak anlamlı fark bulunmadı $(\mathrm{p}>0.05)$ (Tablo 2). İki grubun yaşlarının birbirine yakın olması bu durumu açılayabilir. Vincent ve Pangrazi (37) ise yaş ilerledikçe mantıksal olarak adım uzunluğunun da arttığını ve adım sayısındaki düşüşün öngörülebilir olduğunu vurgulamaktadır.

Ülkemizde ortaokullardaki eğitim şekline göre çocukların okul başlangıç ve bitiş saatleri değişmektedir. Bu çalışmada normal eğitim veren okula devam eden öğrencilerin okul sırasında, okuldan sonra ve hafta içinde günlük ortalama adım sayılarının ikili eğitim veren okula devam eden öğrencilerden yüksek olduğu; okuldan önce günlük ortalama adım sayısının ise ikili eğitim verilen okula devam eden öğrencilerden düşük olduğu belirlendi $(\mathrm{p}<0.05)$ (Tablo 3$)$. Bu durum ikili eğitime devam eden öğlenci grubun sabah saatlerinden okul saatine kadar olan sürelerinin daha fazla olmasından kaynaklanabilir. Çocukların günün büyük bir bölümünü okulda geçirmesi okul saatlerinin önemini arttırmaktadır. Okul saatlerinin çoğu sınıfta geçirilirken, teneffüs ve beden eğitimi dersindeki aktif oyun saati orta-yüksek şiddetli FA için önemli fırsatlar sunmaktadır (18).

Normal eğitim verilen okula devam eden öğrencilerin okul sonrası günlük ortalama adım sayıları ikili eğitim verilen öğrencilerden daha yüksektir (Tablo 5). İki grup arasındaki bu fark normal eğitim veren okula devam eden çocukların okul çıkış saatlerinin ikili eğitim veren okula devam eden öğlenci gruptan daha erken olmasından kaynaklanabilir. Nitekim, Cooper ve ark. (14) saat $15: 30$ 'da okuldan ayrılan çocukların 15:30-16:00 arası FA'larının en yüksek noktaya çlktığını, sonra düşüşe geçtiğini belirtmektedir.

Çocukların hafta içi ve hafta sonu FA düzeyleri değişim gösterebilmektedir. Okul günlerindeki FA ile okul dışı günlerdeki FA'nın karşılaștırılmasının önemli olduğu savunulmaktadır (38). Çocukların hafta içi günlerde hafta sonu günlere göre daha aktif oldukları saptanmıştır $(1,22,35)$. Cooper ve ark. (14), genel olarak çocukların her gün okuldan sonra $40 \mathrm{dk}$ 
dışarıda zaman geçirdiğini belirtmişlerdir. $\mathrm{Bu}$ çalışmada normal eğitim veren okullara devam eden çocukların hafta içi günlük ortalama adım sayılarının ikili eğitim verilen okula devam edenlerden yüksek olduğu ( $\mathrm{p}<0.05)$; hafta sonu günlük ortalama adım sayıları bakımından ise eğitim şekline göre fark olmadığı saptandı ( $>0.05$ ) (Tablo 5).

Sıradan bir okul gününde çocuklar aktif olabilecekleri beden eğitimi, teneffüs/öğle arası ve okul dışı (önce/sonra) sürelerine sahiptirler (29). Teneffüs ve okul dışı zamanlar isteğe bağlı aktivitelerin yapılabileceği zaman dilimi olarak kabul edilmekte ve çocuklar etkinliklere katılımlarını kendileri belirlemektedir (29). Burns ve ark. (23), çocukların günün büyük bir bölümünü okulda geçirmeleri nedeniyle önerilen 12000 adımın en az yarısının (6000 adım) okulda karşılanması gerektiğini savunmaktadır. $\mathrm{Bu}$ çalışmada hafta içinde okul sırasındaki ortalama adım sayısının önerilen 6.000 adımın altında kalıp kalmadığı incelendi ve erkeklerin \%82.8'inin, kızların \%90.3'ünün bu sayıya ulaşamadıkları saptandı. Tüm öğrencilerin ise sadece \%13.3'ünün önerilen adım sayısına ulaștığı belirlendi (Tablo 5). Günün belirli bir bölümünde FA'nın artması için yapılan girişimlerin yararlı olabileceğine dair çalışmalar bulunmaktadır (18). Teneffüs ve öğle aralarında çocukların aktivite düzeylerini arttırmaya yönelik önlemlerin alınması, üzerinde durulması gereken önemli bir konu olarak karşımıza çıkmaktadır.

Sonuç olarak; erkek çocukların günlük adım sayısının kız çocuklarından daha fazla olduğu, normal eğitim verilen okullara devam eden çocukların okul sırasındaki adım sayılarının ikili eğitim verilen okullara devam eden çocuklardan yüksek olduğu belirlendi. Öğrencilerin büyük çoğunluğunun okul sırasında önerilen adım sayısına, yarısından fazlasının ise günlük önerilen adım sayısına ulaşamadıkları saptandı.

\section{KAYNAKLAR}

1. Berglind D, Tynelius P. Objectively measured physical activity patterns, sedentary time and parent-reported screen-time across the day in four-year-old Swedish children. BMC Public Health. 2017;18(1):69.
2. Andersen LB, Riddoch C, Kriemler S, et al. Physical activity and cardiovascular risk factors in children. $\mathrm{Br}$ J Sports Med. 2011;45(11):871-6.

3. Klinker CD, Schipperijn J, Christian H, et al. Using accelerometers and global positioning system devices to assess gender and age differences in children's school, transport, leisure and home based physical activity. Int J Behav Nutr Phys Act. 2014;11(1):8.

4. Biddle SJ, Gorely T, Stensel DJ. Health-enhancing physical activity and sedentary behaviour in children and adolescents. J Sports Sci. 2004;22(8):679-701.

5. WHO. Global Strategy on Diet, Physical Activity and Health. Physical activity and young people. 2011. http://www.who.int/dietphysicalactivity/factsheet_you ng_people/en. Erişim: 23.04.2019.

6. Tudor-Locke C, Pangrazi RP, Corbin CB, et al. BMIreferenced standards for recommended pedometerdetermined steps/day in children. Prev Med. 2004;38(6):857-64.

7. WHO. Global Health Observatory (GHO) data. Prevalence of insufficient physical activity. 2010. http://www.who.int/gho/ncd/risk_factors/physical_act ivity/en/. Erişim: 23.04.2019.

8. Clemes SA, Biddle SJ. The use of pedometers for monitoring physical activity in children and adolescents: measurement considerations. J Phys Act Health. 2013;10(2):249-62.

9. Loprinzi PD, Cardinal BJ, Loprinzi KL, et al. Benefits and environmental determinants of physical activity in children and adolescents. Obes Facts. 2012;5(4):597-610.

10. Pratt M, Macera CA, Sallis JF, et al. Economic interventions to promote physical activity: application of the SLOTH model. Am J Prev Med. 2004;27(3 Suppl):136-45.

11. Dunton GF, Kawabata K, Intille S, et al. Assessing the social and physical contexts of children's leisure-time physical activity: an ecological momentary assessment study. Am J Health Promot. 2012;26(3):135-42.

12. Maddison R, Jiang $Y$, Vander Hoorn S, et al. Describing patterns of physical activity in adolescents using global positioning systems and accelerometry. Pediatr Exerc Sci. 2010;22(3):392-407.

13. Tudor-Locke C, Ainsworth BE, Popkin BM. Active commuting to school: an overlooked source of childrens' physical activity? Sports Med. 2001;31(5):309-13.

14. Cooper AR, Page AS, Wheeler BW, et al. Mapping the walk to school using accelerometry combined with a global positioning system. Am J Prev Med. 2010;38(2):178-83.

15. Faulkner GE, Buliung RN, Flora PK, et al. Active school transport, physical activity levels and body weight of children and youth: a systematic review. Prev Med. 2009;48(1):3-8. 
16. Harding SK, Page AS, Falconer C, et al. Longitudinal changes in sedentary time and physical activity during adolescence. Int J Behav Nutr Phys Act. 2015;12(1):44.

17. Fairclough SJ, Boddy LM, Mackintosh KA, et al. Weekday and weekend sedentary time and physical activity in differentially active children. J Sci Med Sport. 2015;18(4):444-9.

18. Brooke HL, Corder $\mathrm{K}$, Atkin AJ, et al. A systematic literature review with meta-analyses of within-and between-day differences in objectively measured physical activity in school-aged children. Sports Med. 2014;44(10):1427-38.

19. Lubans DR, Plotnikoff RC, Miller A, et al. Using pedometers for measuring and increasing physical activity in children and adolescents: the next step. $\mathrm{Am}$ J Lifestyle Med. 2015;9(6):418-27.

20. Smith NJ, Monnat SM, Lounsbery MA. Physical activity in physical education: are longer lessons better? J Sch Health. 2015;85(3):141-8.

21. McKenzie TL, Crespo NC, Baquero B, et al. Leisuretime physical activity in elementary schools: analysis of contextual conditions. J Sch Health. 2010;80(10):470-7.

22. Brusseau TA, Kulinna PH, Tudor-Locke C, et al. Children's step counts on weekend, physical education, and non-physical education days. J Hum Kinet. 2011;27(1):123-34.

23. Burns RD, Brusseau TA, Hannon JC. Prediction of optimal daily step count achievement from segmented school physical activity. Adv Public Health. 2015. http://dx.doi.org/10.1155/2015/ 496248.

24. Gauthier AP, Laurence M, Thirkill L, et al. Examining school-based pedometer step counts among children in grades 3 to 6 using different timetables. J Sch Health. 2012;82(7):311-7.

25. T.C. Resmi Gazete. Millî Eğitim Bakanlığı okul öncesi eğitim ve ilköğretim kurumları yönetmeliği. 26.07.2014, $\quad$ sayl: 29072. http://www.resmigazete.gov.tr/eskiler/2014/07/2014 0726-4.htm.

26. Fitbit. Fitbit Flex2. https://www.fitbit.com/au/flex2. Erișim: 06.12.2018.

27. Tudor-Locke C, Lee SM, Morgan CF, et al. Children's pedometer-determined physical activity during the segmented school day. Med Sci Sports Exerc. 2006;38(10):1732-8.
28. Demirci N. Okul dışı sportif etkinliklere katılan 11-13 yaşları arasındaki çocukların okul içi ve okul dışı adım sayılarının incelenmesi. Hacettepe Üniversitesi Sağllk Bilimleri Enstitüsü Spor Bilimleri ve Teknolojisi Anabilim Dalı Yüksek Lisans Tezi. Ankara: Hacettepe Üniversitesi; 2017.

29. Beighle A, Morgan CF, Le Masurier G, et al. Children's physical activity during recess and outside of school. $J$ Sch Health. 2006;76(10):516-20.

30. Reşitoğlu HÜ. Diğerleri için duyulan suç korkusu. SDÜ Fen-Edebiyat Fakültesi Sosyal Bilimler Dergisi. 2017;41:145-60.

31. Tandoğan 0 . Kent merkezine yakın yerleşme alanlarında ebeveynin suç korkusu ve çocuğun bağımsız hareket hakkı. T.C. Namık Kemal Üniversitesi Bilimsel Araştırmalar Projeleri Koordinasyon Birimi (NKÜBAP) Bilimsel Araştırma Projesi Sonuç Raporu. 2017. Available from: http://acikerisim.nku.edu.tr:80 80/xmlui/bitstream/handle/20.500.11776/2339/NK UBAP.00.18.AR.15.03.pdf?sequence=1\&isAllowed=y

32. Biddle SJ, Gorely T, Marshall SJ, et al. The prevalence of sedentary behavior and physical activity in leisure time: a study of Scottish adolescents using ecological momentary assessment. Prev Med. 2009;48(2):151-5.

33. Mark AE, Boyce WF, Janssen I. Television viewing, computer use and total screen time in Canadian youth. Paediatr Child Health. 2006;11(9):595-9.

34. Joens-Matre RR, Welk GJ, Calabro MA, et al. Ruralurban differences in physical activity, physical fitness, and overweight prevalence of children. J Rural Health. 2008;24(1):49-54.

35. Troiano RP, Berrigan D, Dodd KW, et al. Physical activity in the United States measured by accelerometer. Med Sci Sports Exerc. 2008;40(1):1818.

36. Tudor-Locke C, Craig CL, Beets MW, et al. How many steps/day are enough? for children and adolescents. Int J Behav Nutr Phys Act. 2011;8(1):78. https://doi.org/10.1186/1479-5868-8-78.

37. Vincent SD, Pangrazi RP. An examination of the activity patterns of elementary school children. Pediatr Exerc Sci. 2002;14(4):432-41.

38. Gavarry O, Giacomoni M, Bernard TH, et al. Habitual physical activity in children and adolescents during school and free days. Med Sci Sports Exerc. 2003;35(3):525-31. 